\title{
НОВЫЙ КАППА-ОПИОИДНЫЙ АНАЛЬГЕТИК БЕЗ НАРКОГЕННОГО ПОТЕНЦИАЛА
}

\author{
Н.В. Елисеева', О.Ю. Гречко', Ю.В. Лифанова', О.Н. Жуковская², \\ А.С. Морковник ${ }^{2}$ \\ ${ }^{1}$ Кафедра фармакологии и биоинформатики, \\ ФГБОУ ВО ВолгГМУ, 400131, Россия, Волгоград, площадь Павших Борцов, 1. \\ ${ }^{2}$ Научно-исследовательский институт физической и органической химии, \\ ФГАОУ ВО ЮФУ, 344006, Россия, Ростов-на-Дону, ул. Большая Садовая, 105/4.
}

DOI: 10.19163/MedChemRussia2021-2021-482

e-mail: nvkirillova@rambler.ru

Многолетние исследования фармакологии азотистых гетероциклов при сотрудничестве с ЮФУ позволили определить класс галогенфенилзамещенных имидазобензимидазолов в качестве источника соединений с каппа-опиоидной рецепторной селективностью. Целенаправленный скрининги последующие выявленные закономерности лиганд-каппа-рецепторных взаимодействий и влияния на $а$ р38 МАРК были реализованы в интегральном скаффолде (2-п-фторфенилимидазо[1,2-а]бензимидазол). Было отобрано соединение-лидер - РУ-1205 9-(2-морфолиноэтил)-2-(4-фторфенил)имидазо[1,2-а]бензимидазол.



Проведен полный цикл доклинических исследований. РУ-1205 оказывает выраженное обезболивающее действие in vivo превосходя эталонные препараты буторфанол и морфин. Всесторонне изучены фармакодинамика, фармакокинетика, наиболее значимые побочные эффекты (дисфория, респираторная депрессия), общая (острая, хроническая токсичность, кумулятивные свойства), специфическая токсичность (эмбриотоксичность, тератогенность, аллергенность, иммунотропность). Отсутствие у РУ-1205 седации и аверсивного действия может быть связано со способностью одновременно проявлять свойства каппа-селективного агониста и ингибитора р38 МАР-киназы, что подтверждается в тестах insilico и УРИМ [1]. Разработаны лекарственные таблетированная и инъекционная лекарственные формы с установленной биоэквивалентностью по отношению к субстанции. Pу-1205 является структурно новым малотоксичным каппа-селективным опиоидным анальгетиком без наркогенного потенциала, может быть предложен для клинических исследований как средство при остром и хроническом болевом синдроме средней и сильной выраженности различной этиологии.

\section{Литература}

[1]. A. A. Spasov, E.E. Zvartau, O.lu. Grechko, etc. Research Results in Pharmacology. - 2020. V. $-6(3)$. P. 59-65. 